\title{
SUGAR BEET MOLASSES: PROPERTIES AND APPLICATIONS IN OSMOTIC DEHYDRATION OF FRUITS AND VEGETABLES
}

\author{
Ljubiša Ć. Šarić , Bojana V. Filipčev, Olivera D. Šimurina, Dragana V. Plavšić, Bojana M. Šarić, \\ Jasmina M. Lazarević, Ivan Lj. Milovanović \\ University of Novi Sad, Institute of Food Technology, Bulevar cara Lazara 1 \\ 21000 Novi Sad, Serbia
}

\author{
*Corresponding author: \\ Phone: +381214853822 \\ Fax: +381 $21450-725$ \\ e-mail address: ljubisa.saric@fins.uns.ac.rs
}

\begin{abstract}
Molasses is an important by-product of sugar beet or sugar cane refining industry and it was one of the first sweeteners used in human nutrition. Sugar cane molasses has unique characteristics that can make it suitable for application in food industry, especially in confectionery and bakery products. On the other hand, sugar beet molasses has not had greater application in the human diet, primarily because of its strong smell and taste of the beet, which makes it unattractive for consumption. Since recent investigations showed that sugar beet molasses can be used as a hypertonic solution in osmotic dehydration of different materials of plant and animal origin, the objective of this work was to review recently studied sugar beet molasses in terms of its applications in osmotic dehydrations of fruits and vegetables. Previous studies showed that sugar beet molasses is an excellent medium for osmotic dehydration of fruits and vegetables (apple, carrot, plum, etc.) primarily due to a high content of dry matter $(80 \%, w / w)$ and specific nutrient content. An important advantage of using sugar beet molasses as a hypertonic solution is an enrichment of the dehydrated material in minerals and vitamins, which penetrate from molasses into the plant tissue. Concentration of sugar beet molasses solution and immersion time had the biggest influence on the process of osmotic dehydration of fruit and vegetables, while the temperature of the solution was the least influential parameter. The effect of immersion time on the kinetics of osmotic dehydration in sugar beet molasses increases with an increase in concentration of hypertonic solution. Fruit and vegetables dehydrated in sugar beet molasses had a higher dry matter content compared to samples treated in sucrose solutions. Besides, application of sugar beet molasses in osmotic dehydration of fruits and vegetables had some other advantages such as lower cost of molasses compared to sugar and its liquid aggregate state. Molasses caused darkening of osmotically treated materials due to transfer of colouring compounds (melanoidins) from molasses solution to plant tissue. The intensity of this darkening depended on immersion time and concentration of molasses solution. An increasing trend in tissue firmness observed in dehydrated samples after $1 \mathrm{~h}$ of immersion was proportional to the concentration of molasses solution.
\end{abstract}

Key words: sugar beet molasses, food, hypertonic solution, fruits, vegetables

\section{INTRODUCTION}

Molasses is an important by-product of sugar beet (Beta vulgaris var. saccharifera) or sugar cane (Saccharum L.) refining industry. Cane and beet molasses are viscous, dark-colored runoff syrups that remain when no more sugar can be economically extracted by crystallization from the raw crop. Molasses was one of the first sweeteners used in human nutrition which has been used very often in the diet of poor population due to its lower price in comparison to refined sugar or honey. Cane sugar was introduced in Europe in the $7^{\text {th }}$ century and continued to be the 
main source of sugar in Europe until the $19^{\text {th }}$ century (Sugar History, n.d.). Since the tropical sugar cane was mainly used for the production, refined sugar was very expensive in Europe (Sugar History, n.d.). Sugar beet was introduced as a sucrose source by German chemist Andreas Margraff and became the main source of sugar in Europe due to good climate conditions for cultivation (Cook and Scott, 1993). Along with growing trend for cultivation of this crop, sugar beet molasses, as a by-product of sugar refining industry became the dominant type of molasses in Europe.

\section{Chemical composition of molasses}

Molasses is a polycomponent system with wide variations in composition mainly due to differences in composition of starting raw material, variation in technological processes during juice purification stage and sucrose crystallization process (Higginbotham and McCarthy, 1998). Molasses mainly consists of fermentable sugars (sucrose, glucose, fructose) and non-sugar substances originating from the compounds that are not precipitated during the purification stage, as well as substances derived by chemical or enzymatic reactions during processing such as D- and Llactic acid, short-chain fatty acids and products of Maillard reaction and Strecker degradation (Higginbotham and McCarthy, 1998).

Molasses is characterized with high content of solids (dry matter). Schiweck (1977, 1995) and Schiweck and Haberl (1973) reported solid content of sugar beet molasses at 74-77\%, while Filipčev and Lević (2014) reported higher value of this parameter $(82 \%)$. Molasses solids consist of $47-48 \%$ of total sugar in which sucrose is the most abundant, whereas other sugars are present in lower amounts: raffinose $(1 \%)$, glucose $(0.25 \%)$ and fructose $(0.25 \%)$ (Schneider, 1968; Petrov and Petrov, 1980). Non-sugar part of molasses encompasses mineral and trace elements such as potassium, sodium, calcium, magnesium, iron, and copper followed by a range of important bioactive compounds such as crude proteins, non-nitrogen substances, vitamin B complex, biotin, etc.
Beet molasses contains remarkable amounts of potassium (around 3.6\%) (Higginbotham and McCarthy, 1998). Šušić and Sinobad (1989) emphasized that the minerals in molasses are dissolved and thus able to be readily absorbed in the organism. They stated that the high potassium content makes molasses particularly attractive for use in human nutrition. Beet molasses has marked antioxidative potential and has been recognized as suitable to be exploited on a large scale as a source of antioxidants and as an ingredient in functional foods (Chen et al., 2015; Chou, 2003). High antioxidant capacity of molasses is attributable to the presence of phenolic compounds, their derivatives, melanins, melanoidins and products of sugar caramelization (Filipčev et al., 2016).

One of the most intriguing compound, abundant in beet but absent in cane molasses, is betaine. Though not essential, betaine became interesting since it was discovered to contribute to normal homocysteine metabolism and thus lowered risk from a range of non-communicable diseases related to Western life style (Craig, 2004). Beet molasses is one of most excellent sources of betaine, suitable to increase betaine content in, for example, baked food (Filipčev et al., 2015; 2016).

In production and trade, the content of sucrose, dry matter, volatile acids, invert sugar and $\mathrm{pH}$ value are the most important parameters for the assessment of molasses quality. These factors influence the stability of molasses and their values may indicate changes in molasses quality during storage. Beet and cane molasses exhibit significant differences regarding to nitrogenous compounds, fermentable sugars, ash and vitamin content (Higginbotham and McCarthy, 1998). Chemical composition of molasses of different origin is shown in Table 1.

There is a difference between the USA and European standards regarding the content of total sugars and dry matter. European standard requires total sugar content to range from 47 to $48 \%(\mathrm{w} / \mathrm{w})$ and dry matter content of $74-77 \%(w / w)$. 
Table 1.

Chemical composition of molasses of different origin

\begin{tabular}{|c|c|c|c|c|c|c|c|}
\hline Molasses origin & $\begin{array}{c}\text { Dry } \\
\text { matter } \\
\%\end{array}$ & $\begin{array}{c}\text { Total } \\
\text { sugars } \\
\%\end{array}$ & $\begin{array}{c}\text { Sucrose } \\
\%\end{array}$ & $\begin{array}{c}\text { Invert } \\
\text { sugar } \\
\%\end{array}$ & $\begin{array}{c}\text { Proteins } \\
\%\end{array}$ & $\begin{array}{c}\text { Ash } \\
\%\end{array}$ & $\mathrm{pH}$ \\
\hline & 83.3 & 50.8 & 49.7 & 1.15 & - & 12.6 & 7.1 \\
\hline & 75.7 & 46.6 & - & - & 11 & 9.8 & - \\
\hline Sugar & 75.1 & 45.5 & - & - & 11 & 10 & - \\
\hline \multirow[t]{4}{*}{ beet } & 77.0 & 48.0 & - & - & 6.0 & 8.7 & - \\
\hline & $\begin{array}{l}81.0 \\
84.0\end{array}$ & $\begin{array}{l}50.0 \\
52.0\end{array}$ & 51 & 0.5 & $12-13$ & $11-12$ & - \\
\hline & 83.5 & 52.5 & - & - & 5.0 & 11.5 & - \\
\hline & 73.7 & 47.1 & - & - & 4.0 & 10.3 & - \\
\hline Sugar & 79.5 & 53.0 & 34 & 19 & 2.2 & 9.5 & 5.0 \\
\hline cane & 75.0 & 46.0 & - & - & 3.0 & 8.1 & - \\
\hline Blackstrap & 71.3 & 60.7 & - & - & 0.0 & 8.2 & - \\
\hline Blackstrap & 74.0 & 46.0 & - & - & 4.0 & 10.1 & - \\
\hline
\end{tabular}

Adopted from Filipčev and Lević (2014)

On the other hand, the USA standard sets contents of total sugars and dry matter in range $48-50$ and $80-84 \%(\mathrm{w} / \mathrm{w})$, respecttively (Higginbotham and McCarthy, 1998). In Serbia, the minimum value of dry matter of sugar beet molasses should be $76.3^{\circ} \mathrm{Bx}$, while its sugar content determined by polarimetry should have minimum value of $46 \%$ (SRPS, 1963); $\mathrm{pH}$ value should be in the range from 7.0 to 8.0 (SRPS, 1963). According to current national regulative (Pravilnik, 2013) sulphur dioxide content in sugar beet molasses should not exceed the limit of $70 \mathrm{mg} / \mathrm{kg}$.

\section{Application of molasses in food in- dustry}

According to the regulations of the US Food and Drug Administration (FDA) sugar cane molasses is classified in the category of GRAS (Generally Recognized as $\underline{\text { Safe) }}$ as natural, harmless extract. Since the global food market recognized refined sugar as too processed and concentrated substance, there is a trend for its substitution with less processed and more natural sweetener (Hickenbottom, 1996). Although not realized by many, cane molasses is suitable for application in food industry, especially in confectionery and bakery industry (Hickenbottom, 1996). Its unique aroma of caramels, bitter and sweet taste could be very useful in masking of unpleasant, raw aroma of bran and linseeds in bakery products (Filipčev and Lević, 2014). Furthermore, it fits well with the aroma of vanilla, chocolate, coffee, anise, maple, pralines, roasted peanuts and rum (Filipčev and Lević, 2014; Filipčev et al., 2015). Owing to its dark colour, molasses can be used as a natural colouring agent to mask grey nuances in rye or whole wheat bread. Beside these characteristics, it could also be considered as food with high nutritional value. Since molasses is rich source of macro elements (potassium, calcium, magnesium, iron) it can successfully be used for fortification of different food products.

Among all types of molasses, sugar cane molasses is the most commonly used in confectionery and bakery applications ( $\mathrm{Hi}-$ ckenbottom, 1996).

On the contrary, sugar beet molasses has not had greater application in the human diet, primarily because of its distinct earthy taste, which makes it unattractive for consumption per se (Filipčev and Lević, 2014). However, numerous studies have shown that it is possible to incorporate sugar beet molasses in various food products without negatively affecting their palatability. Food enriched with beet molasses showed enhanced mineral and antioxidant profile (Filipčev et al., 2010, 2012, 2016). It can be used to supplement wheat bread at 5-10\% level (flour basis), at up to $25 \%$ in semi-sweet biscuits, and as honey replacer at up to $50 \%$ in formulations of ginger bread-type biscuits ( $\mathrm{Fi}$ lipčev et al., 2010, 2012; Šimurina et al., 2006). 
Molasses contains compounds which can be promoters or inhibitors of microbial growth such as pantothenic acid, inositol, and trace elements and, to a lesser extent, biotin. Therefore, it is used as a substrate in biochemical transformations (Higginbotham and McCarthy, 1998). On industrial-scale, sugar beet molasses is widely used as a substrate in fermentations during production of baker's and brewer's yeasts, ethanol, citric acid, lysine and monosodium glutamate (Filipčev and Lević, 2014).

Recent investigations showed that sugar beet molasses can be used as a hypertonic solution in osmotic dehydration of fruits and vegetables owing to its high content of dry matter (Filipčev and Lević, 2014). It was also found efficient in the osmotic dehydration of fish and pork meat (Filipović et al., 2012). Molasses is liquid despite the high dry matter content, which can be very important from the technological point of view regarding its implementation in osmotic dehydration process.

\section{Application of sugar beet molasses in osmotic dehydration of fruits and vege- tables}

Osmotic dehydration of fruit and vegetables

Preserving food products in order to extend their shelf-life, with ensuring their safety and quality, is one of the main goals of the food industry sector. The microbiological quality of fruits and vegetables is limited and mainly related to their high water content and $a_{w}$ value (Yadav and Singh, 2014). Osmotic dehydration is an effective way to reduce moisture content and increase the shelf life of fruits and vegetables with minimal changes of their quality (Lazarides, 2001). It is a water removal process, which is based on soaking foods in a hypertonic solution. Concerning the fact that osmotic dehydration is a process which includes mild product treatment at relatively low process temperatures (Lazarides, 2001), it enables retention of vitamins and minerals, colour, flavour and taste of starting material in the final product.

Conventional preservation methods (convective drying, candying, freezing etc.) often cause decreasing in nutritional and sensory quality of treated fruits and vegetables (loss of vitamins, changes in colour, altered taste and texture, bad rehydration) (Mišljenović et al., 2011).

The driving force for the osmotic dehydration process is the difference in osmotic pressure between the food material (hypotonic solution) and osmotic solution (hypertonic media).The diffusion of water is accompanied by the simultaneous counter diffusion of solute from the osmotic solution into the tissue.

Table 2.

Examples of osmotic dehydration of fruits and vegetables

\begin{tabular}{|c|c|c|}
\hline Material & Hypertonic solution & Description \\
\hline Apple & $\begin{array}{l}\text { Sucrose } \\
\left(50,60,70^{\circ} \mathrm{Bx}\right)\end{array}$ & Peeled \\
\hline Pineapple & $\begin{array}{l}\text { Sucrose } \\
\left(50,60,70^{\circ} \mathrm{Bx}\right)\end{array}$ & Peeled \\
\hline Banana & $\begin{array}{l}\text { Sucrose } \\
\left(40,50,60,70{ }^{\circ} \mathrm{Bx}\right)\end{array}$ & Peeled, cylinders $25 \times 45 \mathrm{~mm}$ \\
\hline Cherry tomato & $\begin{array}{l}10,25 \%(\mathrm{w} / \mathrm{w}) \mathrm{NaCl} \\
\mathrm{NaCl}: \text { sucrose }(3: 2)\end{array}$ & Needle-perforated fruits \\
\hline Melon & $\begin{array}{l}\text { Sucrose } \\
\left(45-50^{\circ} \mathrm{Bx}\right)\end{array}$ & Peeled \\
\hline Chestnut & $\begin{array}{l}\text { Glucose } \\
\left(40,50,60^{\circ} \mathrm{Bx}\right)\end{array}$ & Peeled \\
\hline Mushrooms & $10,15 \%(\mathrm{w} / \mathrm{w}) \mathrm{NaCl}$ & Halves \\
\hline Pear & Sucrose $\left(55^{\circ} \mathrm{Bx}\right)$ & Cubes $1 \mathrm{~cm}^{3}$ \\
\hline Peach & Sucrose $\left(65-80^{\circ} \mathrm{Bx}\right)$ & - \\
\hline Blueberries & Sucrose $\left(60-80^{\circ} \mathrm{Bx}\right)$ & - \\
\hline Mango & Sucrose $\left(60^{\circ} \mathrm{Bx}\right)$ & Pieces, $10 \mathrm{~mm}$ \\
\hline
\end{tabular}

Adopted from Filipčev and Lević (2014) 
Considering the cell membrane is not perfectly selective, other solutes present For fruits and vegetables dehydration, the most commonly used osmotic agents are sucrose and sodium chloride and their combinations. Glucose, fructose, maltodextrin and sorbitol can also be used as osmotic agents in osmotic dehydration (Yadav and Singh, 2014). Examples of osmotic dehydration of different fruits and vegetables are shown in Table 2.

Osmotic dehydration of fruits and vegetables consists of several stages: washing, peeling and slicing or cubing (if required), sulphiting (optional), immersing in heated osmotic solution, rinsing, draining, further processing (vacuum drying, air drying, freeze drying, freezing) and packaging. After size reduction of fruits the different pretreatments such as curing or chlorination can be performed, while vegetables should always be blanched by dipping the pieces in heated water (Falade and Igbeka, 2007). Factors that influence the osmotic dehydration process can be classified into two groups: product parameters and process parameters (Lazarides, 2001). Following factors fall into the first group: porosity and structure of material (that depend on its maturity, cultivation and climate conditions, etc.), size and shape of material as well as pretreatment (peeling, blanching, freezing). The process parameters are concentration and type of osmotic solution, temperature of osmotic solution, applied pressure, immersion time, a weight ratio of solution to material and agitation (Lazarides, 2001).

Osmotic dehydration of fruits and vegetables in sugar beet molasses as hypertonic solution

The most commonly used hypertonic solutions in the processes of osmotic dehydratation are concentrated solutions of sucrose, $\mathrm{NaCl}$ or their combinations (Mišljenović et al., 2011). Recent research data have shown that use of sugar beet molasses as hypertonic solution improves osmotic dehydration processes. Sugar beet molasses is an excellent medium for osmotic dehydration, primarily due to a high solid content $(80 \%, w / w)$, liquid ag- in the cells can diffuse into the osmotic solution (Mišljenović et al., 2011). gregate state, and specific nutrient content: $51 \%$ saccharose, $1 \%$ raffinose, $0.25 \%$ glucose and fructose, $5 \%$ proteins, $6 \%$ betaine, $1.5 \%$ nucleosides, purine and pyrimidine bases, organic acids and bases; which subsequently results in a high osmotic pressure of the solution. From nutrient point of view, an important advantage of sugar beet molasses as a hypertonic solution is its ability to enrich the treated food material with minerals and vitamins, which penetrate from molasses into the plant tissue (Mišljenović et al., 2011). From technological point of view, the main asset of molasses would be its liquid state and high solid content since this ensures advance in comparison to, for example, usage of high concentration sucrose solutions which is associated to numerous problems such as slow dissolution of sucrose and its continuous recrystallization during the process (Filipčev and Lević, 2014). On the other hand, high viscosity of molasses at lower temperatures may require a use of higher quality and more expensive pumps to ensure efficient circulation of osmotic solution during osmotic dehydration.

Temperature, immersion time and concentration of hypertonic solution primarily affect the osmotic dehydration process. Higher values of these parameters induce intensification of water removal and increase in dry matter content. Higher concentrations of hypertonic solution facilitate the removal of water from material tissues, while higher temperatures of hypertonic solution increase membrane permeability and decrease the viscosity of concentrated solutions, thereby reducing resistance to the mass transfer. However, previous research has shown that these factors do not always equally influence the process parameters. According to Mišljenović (2012), concentration of sugar beet molasses solution and immersion time had the biggest influence on the process of osmotic dehydration of apple and carrot, while the temperature of the solution was the least influential parameter. Comparing the kinetics of osmotic dehydrations of 
apple and carrot in the sugar beet molasses and sucrose solutions, Koprivica (2013) observed that, in the case of molasses, the immersion time had a greater impact on kinetics than the concentration of hypertonic solution, while in the experiment with sucrose, concentration of hypertonic solution was the predominant factor. The impact of immersion time on the kinetics of osmotic dehydration in sugar beet molasses increases with an increase in concentration of hypertonic solution. This could be explained by the high viscosity of sugar beet molasses solution. The circulation of osmotic solution increases mass transfer rates between the treated samples of apple/carrot and the hypertonic solution. This is particularly apparent in highly concentrated solutions due to their high viscosity.

The ratio of water loss to solids gain (WL/SG) is a good index of the efficiency of the osmotic dehydration process. Application of sugar beet molasses as hypertonic solution in osmotic dehydration of apple resulted in higher WL/SG ratios in comparison to application of $70 \%$ sucrose solution. Considering the WL/SG ratio, the best parameters for osmotic dehydration of apple and plum in sugar beet molasses were undiluted molasses heated to $45^{\circ} \mathrm{C}$ and immersion time of $3 \mathrm{~h}$ (Koprivica et al., 2010; Koprivica et al., 2014). The best results regarding final dry matter content in osmotically treated red cabbage were achieved by using undiluted sugar beet molasses with immersion time of $5 \mathrm{~h}$ (Mišljenović et al., 2009; Mišljenović et al., 2010). The highest increase in dry matter content in osmodehydrated carrot was achieved with $80 \% \quad(\mathrm{w} / \mathrm{w})$ molasses solution in water, temperature of $45{ }^{\circ} \mathrm{C}$ and immersion time of $5 \mathrm{~h}$ (Mišljenović et al., 2011). At the end of the osmotic dehydration process, the dry matter content $(63.4 \% \mathrm{w} / \mathrm{w})$ in treated apple was 5 times higher than in fresh apple (Mišljenović et al., 2010).

The osmotic agents also reduce water activity of the dehydrated samples. For example, water activity of carrot pieces dehydrated in sugar beet molasses solution under optimal conditions was reduced from 0.99 to 0.86 (Mišljenović et al.,
2012). The reduction of water activity of osmotic treated samples indicates that osmotic dehydration process can be effective against microbial growth. On the other hand, application of lower concentrations of hypertonic solution (30 and $40 \% \mathrm{w} / \mathrm{w}$ did not lead to decrease in water activity enough to affect microbial growth. Mišljenović (2012) reported that application of sugar beet molasses as hypertonic solution in osmotic dehydration of apple and carrot was more effective than using sucrose solution. Namely, samples dehydrated in sugar beet molasses had a higher dry matter content compared to samples treated in sucrose solutions under the same experimental conditions. As already mentioned above, additional advantage of sugar beet molasses application in osmotic dehydration of fruits and vegetables is improvement in the nutritional value of the treated samples. $\mathrm{Na}$ mely, the sugar beet molasses represents a natural source of bioactive elements and compounds such as vitamins, minerals and antioxidants, which can migrate from hypertonic solution to plant tissues. In line with that, Filipčev et al. (2008) reported an increased content of $\mathrm{K}, \mathrm{Na}, \mathrm{Mg}$ and $\mathrm{Ca}$ in apple samples dehydrated in sugar beet molasses solution. Similarly, Koprivica (2013) observed a higher content of minerals (particularly $\mathrm{K}, \mathrm{Mg}$ and $\mathrm{Ca}$ ) in apple and carrot samples treated in sugar beet molasses. On the contrary, significant loss of minerals was determined in the samples of apple and carrot osmotically treated in sucrose solution (Koprivica, 2013).

As a semi-permeable system, the cell membrane of plant tissue is a barrier to most, but not all molecules. Many different molecules, including molecules of vitamins, minerals and organic acids can pass through the membrane by diffusion into osmotic solution. The reduction in nutritive value of samples dehydrated in sucrose solution is a result of this diffusion processes.

The dark colour of molasses causes darkening of osmotically treated materials which can affect quality of the final products and their acceptance by consumers. Changes in $L^{*}$ parameter (lightness) during osmotic dehydration of carrot and ap- 
ple were determined in both sucrose and sugar beet molasses solutions (Filipčev and Lević, 2014). Furthermore, the darkening of apple dehydrated in sugar beet molasses solutions was more intensive than darkening of the apple samples treated in sucrose solutions. This could be explained by transfer of coloured compounds (melanoidins) from molasses solution to plant tissue. In the experiments performed with sucrose solutions, the darkening of apple and carrot occurred gradually over all $5 \mathrm{~h}$ of the process, while significant $(p<0.05)$ darkening of this fruits in sugar beet molasses solutions occurred after just $1 \mathrm{~h}$ (Filipčev and Lević, 2014). Similar was observed even in the solutions of low molasses concentration. There was no statistically significant difference in the lightness between samples dehydrated for 1 and $3 \mathrm{~h}$ in solutions of different concentrations of sugar beet molasses (Koprivica, 2013), which indicates that an increase in molasses concentration did not affect the value of $L^{*}$ parameter under these experimental conditions. The concentration of molasses solution had significant $(p<0.05)$ impact on the lightness of treated samples only for immersion time of $5 \mathrm{~h}$. In this case, an increase in immersion time significantly $(p<0.05)$ decreases lightness of apple dehydrated in highly concentrated molasses solutions. On the other hand, the immersion time increase did not affect the lightness of the samples treated in molasses solutions of low concentration. The circulation of molasses solution stimulates transfer of colouring compounds from molasses to sample tissue and darkening of dehydrated samples.

When a fruit or vegetable is submitted to a dehydration process, associated heat and mass transfer gradients produce changes in the physical and structural characterristics of the plant tissue, such as changes in volume and porosity, as well as changes in mechanical properties (Mayor et al., 2008). When the plant tissue is placed in hypertonic solution, water will leave the cell by osmosis. As a result, the vacuole and the rest of the protoplasm will shrink, causing the plasma membrane to pull away from the cell wall. This phenomenon is known as plasmolysis, and it has been observed during osmotic dehydration of potato and strawberry. Plasmolysis is accompanied with a loss in the turgor pressure, shrinkage and deformation of cells (cell wall and plasma membrane), and concentration of the protoplasmatic liquid phase. Cellular shrinkage has been observed during osmotic dehydration of apple (Mayor et al., 2008). Koprivica (2013) reported changes of the apple tissue firmness during osmotic dehydration in hypertonic solutions of sucrose and sugar beet molasses. Significant $(p<0.05)$ reduction of apple tissue firmness (in comparison to fresh fruit) was observed after $1 \mathrm{~h}$ of immersion in both types of solutions. After that period, an increasing trend in tissue firmness was recorded. This phenomenon was particularly pronounced in samples dehydrated in sugar beet molasses solution due to transfer of calcium ions from molasses to the apple tissue. This increasing trend was proportional to concentration of molasses solution. At the end of the osmotic dehydration process, with immersion time of $5 \mathrm{~h}$, apple tissue firmness was nearly equal to the firmness of fresh apple tissue (Koprivica, 2013).

\section{CONCLUSIONS}

It can be concluded that sugar beet molasses could be successfully used as a hypertonic solution in osmotic dehydration of fruits and vegetables, owing to its high content of dry matter. The osmotic solutions of sugar beet molasses markedly increased the amount of mineral substances in the treated fruits/vegetables, and therefore enhanced their nutritive profile. Higher solution concentration and longer immersion time resulted in higher water loss and solid gain, while solution temperature showed to be the least influential parameter in the osmotic dehydration process. Due to high viscosity of beet molasses, immersion time exerts higher impact on osmotic dehydration than does the concentration of hypertonic solution. Circulation of the molasses solution showed important influence on the final dry matter content in the osmodehydrated plant material. Fruits, osmotically dehydrated in pure sucrose solution, had a lower dry matter content as well as softer 
and gentler texture in comparison to fruits dehydrated in high concentrated molasses solutions. Sugar beet molasses caused darkening of osmotically dehydrated fruits and vegetables, which intensity depended on immersion time and concentration of molasses solution.

Low cost of molasses and the unique association of liquid aggregate state and high solid content represent the major advantages of sugar beet molasses application in osmotic dehydration process. The major hindrances would be higher initial costs for circulating pumps due to higher viscosity of molasses and intensive colouring of the treated material and impact on its palatability which may largely affect the further use of the osmodehydrated material. To illustrate a possible way to utilize osmodehydrated fruits/vegetables in beet molasses, it was reported a successful incorporation of wet and powdered osmodehydrated apple, plum, carrot and red cabbage in wheat bread (Filipčev et al., 2010).

\section{ACKNOWLEDGMENTS}

This work is a part of the National Project (TR-31055) financially supported by the Ministry of Education, Science and Technological Development, Republic of Serbia.

\section{REFERENCES}

1. Chen, M., Zhao, Y., Yu, S. (2015). Optimisation of ultrasonic-assisted extraction of phenolic compounds, antioxidants, and anthocyanins from sugar beet molasses. Food Chemistry, 172, 543-550.

2. Chou, C.C. (2003). Preparation antioxidants enriched functional food products from sugar cane and beet. United States Patent Applications \#127141.

3. Cook, D.A., Scott, R.K. (eds.) (1993). The Beet Sugar Crop, Chapman and Hall, London.

4. Craig, S.A.S. (2004). Betaine in human nutrition. American Journal of Clinical Nutrition, 80 , 539-548.

5. Curtin, L.V. (1983). Molasses-General Consideration, National Feed Ingredients Association, West des Moines, lowa, USA.

6. Falade, K.O., Igbeka, J.C. (2007). Osmotic dehydration of tropical fruits and vegetables. Food Reviews International, 23 (4), 373-405.

7. Filipčev, B., Bodroža-Solarov, M., Šimurina, O., Cvetković, B. (2012). Use of sugar beet molasses in processing of gingerbread type bis- cuits: effect on quality characteristics, nutritional profile, and bioavailability of calcium and iron. Acta Alimentaria Hungarica, 41 (4), 494505.

8. Filipčev, B., Lević, Lj., Bodroža-Solarov, M., Mišljenović, N., Koprivica, G. (2010). Quality characteristics and antioxidant properties of breads supplemented with sugar beet molasses-based ingredients. International Journal of Food Properties, 13, 1035-1053.

9. Filipčev, B., Šimurina, O., Dapčević Hadnađev, T., Jevtić-Mučibabić, R., Filipović, V., Lončar, B. (2015). Effect of liquid (native) and dry molasses originating from sugar beet on physical and textural properties of gluten-free biscuit and biscuit dough. Journal of Textural Studies, 46, 353-364.

10. Filipčev, B., Lević, Lj., Pribiš, V., Kabić, D. (2008). Melasa šećerne repe kao pogodan hipertoničan rastvor za osmotski predtretman jabuke. XIII savetovanje o biotehnologiji, Čačak, Srbija, Zbornik radova, 13 (14), 323329.

11. Filipčev, B., Lević, Lj. (2014). Primena melase šećerne repe i poluproizvoda od osmotski dehidriranog voća - povrća u melasi kao nutritivno vrednih dodataka za obogaćivanje pekarskih i finih pekarskih proizvoda, Monografija, Univerzitet u Novom Sadu, Naučni institut za prehrambene tehnologije u Novom Sadu, Novi Sad.

12. Filipčev, B., Mišan, A., Šarić, B., Šimurina, O. (2016). Sugar beet molasses as an ingredient to enhance the nutritional and functional properties of gluten-free cookies. International Journal of Food Sciences and Nutrition, 67, 249-256.

13. Filipčev, B.V., Brkljača, J.S., Krulj, J.A., Bodroža-Solarov, M.I. (2015). The betaine content in common cereal-based and gluten-free food from local origin. Food and Feed Research, 42, 129-137.

14. Filipović, V., Ćurčić, B., Nićetin, M., Plavšić, D., Koprivica, G.M. (2012). Mass transfer and microbiological profile of pork meat dehydrated in two different osmotic solutions. Hemijska industrija, 66 (5), 743-748.

15. Hickenbottom, J. (1996). Use of molasses in bakery products. AIB Technical Bulletin, XVIII (6), 1-6.

16. Higginbotham, J.D., McCarthy, J. (1998). Quality and storage of molasses. In Sugar Technology-Beet and Cane Manufacture. Eds. P.W. van der Poel, H. Schiweck, T. Schwartz, Verlag Dr. Albert Bartens KG, Berlin, Germany, pp. 973-992.

17. Koprivica, G. (2013). Nutritivni profil i senzorski kvalitet osmotski dehidriranog voća i povrća u rastvorima melase šećerne repe i saharoze. Doktorska teza, Tehnološki fakultet, Univerzitet u Novom Sadu, Srbija.

18. Koprivica, G., Mišljenović, N., Lević, Lj., Jevrić, L. (2010). Mass transfer kinetics during osmotic dehydration of plum in sugar beet molasses. 
Journal on Processing and Energy in Agriculture, 14 (1), 27-31.

19. Koprivica, G., Pezo, L., Ćurčić, B., Lević, Lj., Suput, D. (2014). Optimization of osmotic dehydration of apples in sugar beet molasses. Journal of Food Processing and Preservation, 38 (4), 1705-1715.

20. Lazarides, H. (2001). Reasons and possibilities to control solid uptake during osmotic treatment of fruits and vegetables. In Osmotic dehydration \& vacuum impregnation: Applications in food industries. Eds. U.P. Fito, A. Chiralt, J.M. Barat, D. Behsnilian, Technomic Publ., Lancaster, USA, pp. 33-42.

21. Mayor, L., Pissarra, J., Sereno A.M. (2008). Microstructural changes during osmotic dehydration of parenchymatic pumpkin tissue. Journal of Food Engineering, 85, 326-339.

22. Mišljenović, N. (2012). Osmotska dehidratacija u melasi šećerne repe i rastvorima saharoze kao energetski efikasan i ekološki prihvatljiv tehnološki postupak povećanja održivosti voća i povrća, Doktorska teza, Tehnološki fakultet, Univerzitet u Novom Sadu, Srbija.

23. Mišljenović, N., Koprivica, G., Jevrić, L., Lević, Lj. (2011). Mass transfer kinetics during osmotic dehydration of carrot cubes in sugar beet molasses. Romanian Biotechnological Letters, 16 (6), 6790-6799.

24. Mišljenović, N., Koprivica, G., Lević, Lj. (2010). Comparison of the kinetics of osmotic drying apples in sugar beet molasses and sucrose solutions. Journal on Processing and Energy in Agriculture, 14 (1), 32-35.

25. Mišljenović, N., Koprivica, G., Pezo, L., Lević, L., Ćurčić, B., Filipović, V., Nićetin, M. (2012). Optimization of the osmotic dehydration of carrot cubes in sugar beet molasses. Thermal Science, 16 (1), 43-52.
26. Mišljenović, N., Koprivica, G., Lević, Lj., Filipčev, B., Kuljanin, T. (2009). Osmotic dehydration of red cabbage in sugar beet molasses-mass transfer kinetics. Acta Periodica Technologica (APTEF), 40, 145-154.

27. Petrov, S., Petrov, L. (1980). Priručnik za industriju šećera (Tom. Knjiga I, Deo III), Štamparija PTT, Beograd.

28. Pravilnik (2013). Pravilnik o prehrambenim aditivima. Sl. glasnik RS, 63/2013.

29. Schiweck, H. (1977). Die Konzentration einiger Melasseinhaltsstoffe in Melassen verschieden Provenienz. Branntweinwirtschaft, 117, 87-93.

30. Schiweck, H. (1995). Zuckerindustrie, 120, 273282.

31. Schiweck, H., Haberl, L. (1973). Branntweinwirthschaft, 113, 76-83.

32. Schneider, F. (1968). Technologie des Zuckers, Verlag, M. and H. Schaper, Hannover.

33. SRPS (1963). Određivanje šećera u melasi (polarimetrijski). SRPS E.L3.020:1963.

34. Sugar History (n.d.). Sugar Beet History and Facts.

(www.sugarhistory.net/sugar-making/sugarbeet).

35. Šimurina, O., Filipčev, B., Lević, Lj., Pribiš, V., Pajin, B. (2006). Sugar beet molasses as an ingredient in tea-cookie formulation. Journal on Processing and Energy in Agriculture, 10 (3-4), 93-96.

36. Šušić, S., Sinobad, V. (1989). Ispitivanja u cilju unapređenja industrije šećera Jugoslavije. Hemijska Industrija, 43 (1-2), 10-21.

37. Yadav, A.K., Singh, S.V. (2014). Osmotic dehydration of fruits and vegetables: a review. Journal of Food Science and Technology, 51, 1654-1673. 


\section{МЕЛАСА ШЕЋЕРНЕ РЕПЕ: СВОЈСТВА И ПРИМЕНА У ОСМОТСКОЈ ДЕХИДРАТАЦИЈИ ВОЋА И ПОВРЋА}

Љубиша Ћ. Шарић, Бојана В. Филипчев, Оливера Д. Шимурина, Драгана В. Плавшић, Бојана М. Шарић, Јасмина М. Лазаревић, Иван Љ. Миловановић

Универзитет у Новом Саду, Научни институт за прехрамбене технологије у Новом Саду, 21000 Нови Сад, Булевар цара Лазара бр. 1, Србија

Сажетак: Меласа је важан споредни производ индустрије производње шећера из шећерне репе или шећерне трске и један од првих заслађивача који је коришћен у људској исхрани. Меласа шећерне трске има јединствене карактеристике које је чине погодном за примену у индустрији хране, посебно у кондиторској и пекарској индустрији. Насупрот томе, меласа шећерне репе до сада није имала већу примену у исхрани људи, пре свега због израженог мириса и укуса на репу, који је чини непривлачном за конзумацију. С обзиром да су скорија истраживања показала да се меласа шећерне репе може користити као хипертонични раствор у осмотској дехиратацији различитих материјала биљног и животињског порекла, циљ овог рада је био преглед новијих истраживања меласе шећерне репе у смислу њене примене у осмотској дехидратацији воћа и поврћа. Претходне студије су показале да је меласа шећерне репе изврстан супстрат за осмотску дехидратацију воћа и поврћа (јабука, шаргарепа, шљива, итд.), првенствено због високог садржаја суве материје $(80 \% \mathrm{~m} / \mathrm{M})$ и специфичног нутритивног састава. Значајна предност коришћења меласе шећерне репе као хипертоничног раствора је у обогаћењу дехидрисаног материјала минералима и витаминима, који пенетрирају из меласе у биљно ткиво. Концентрација раствора меласе шећерне репе и време имерзије су имали највећи утицај на процес осмотске дехидратације воћа и поврћа, док је температура раствора била најмање утицајан параметар. Ефекат времена имерзије на кинетику осмотске дехидратације у меласи шећерне репе расте са порастом концентрације хипертоничног раствора. Узорци воћа и поврћа дехидрисани у меласи шећерне репе су имали већи садржај суве материје у поређењу са узорцима третираним у растворима шећера. Осим тога, примена меласе шећерне репе у осмотској дехидратацији воћа и поврћа је имала и друге предности, као што су нижа цена у односу на шећер и њено течно агрегатно стање. Меласа је узроковала тамњење осмотски третираног материјала због трансфера бојених материја (меланоидина) из раствора меласе у биљно ткиво. Интензитет тамњења је зависио од времена имерзије и концентрације раствора меласе. Тренд пораста чврстоће ткива забележен у дехидрираним узорцима након 1 сата имерзије је био пропорционалан концентрацији раствора меласе.

Кључне речи: меласа шећерне репе, храна, хипертонични раствор, воће, поврће

Received: 17 November 2016

Accepted: 23 December 2016 